\title{
Empirical Analysis of Sports Participation through Sarjana Pendamping Penggerak Pembangunan Olahraga (SP3OR) Deployments
}

\author{
Endi Rustandi* \\ Fakultas Keguruan dan Ilmu Pendidikan \\ Universitas Majalengka \\ Majalengka, Indonesia \\ *endi.rustandi@unma.ac.id
}

\author{
Adang Suherman, Amung Ma'mun \\ Fakultas Pendidikan Olahraga Kesehatan \\ Universitas Pendidikan Indonesia \\ Bandung, Indonesia \\ adangsuherman@upi.edu
}

\begin{abstract}
Government efforts to develop sports as stated in article 21 paragraph 4 of Law No. 03 of 2005 concerning the national sports system that coaching and developing sports is carried out through family channels, educational channels, and community channels based on the development of sports for all people for a lifetime. In connection with that, the provincial government of West Java through service and youth sports in 2010 has submitted a Bachelor of Sports Development Trainer or Sarjana Pendamping Pengerak Pembangunan Olahraga (SP3OR) with a total of 78 people distributed to 78 districts in 26 districts in West Java. The main purpose of the spread of the power of SP3OR is to motivate the West Java community to carry out activities or make the need for sports and cultural life so that the number of community sports participants (APMO) of $50 \%$ in 2017 can be achieved. The evaluation of this study aims to find out and explain how the program implementation of the Bachelor of Sports Development Trainers (SP3OR), whose principles are oriented towards improvement and improvement of the program. The research method used is a survey. Based on data obtained until 2016 the level of sports participation (APMO) in West Java was $32.04 \%$.
\end{abstract}

\section{Keywords-SP3OR; sport participation}

\section{INTRODUCTION}

Government efforts to develop sports as stated in Article 21 paragraph 4 of Law No. 03 of 2005 concerning the National Sports System which states that "The development of sports is carried out through family channels, educational channels, and community channels based on the development of sports for everyone that lasts a lifetime" [1]. Today it is not easy to expect presence sports activists in the community who voluntarily provide their time and thoughts for the benefit of society. Based on national data from the 2015 Central Bureau of Statistics (BPS) census, the interest of Indonesian youth in exercising is still low, with data showing $28.22 \%$. Among young people who exercise, about $40 \%$ of them aim to maintain health. Around a quarter of them do exercise as hobbies/recreation. About $28.19 \%$ of youth do exercise because of the curriculum in the school. In general, the main channels/media for exercising for youth are themselves and schools. Youth who attend sports associations are only $18.13 \%$. The main type of sport that is mostly carried out by youth is football / futsal $(30.38 \%)$. The types of sports with the second and third largest percentages are jogging/walking and gymnastics (18.32\% and $19.23 \%$, respectively) [2]. "An active lifestyle characterized by sports participation is an important factor in determining health, well-being, and work productivity" [3]. shows that physical activity carried out regularly can reduce the risk of cardiovascular disease, type 2 diabetes, and some cancers in women between 14-58\% [4]. The results of other studies say that those who engage in moderate physical activity for 30 minutes with a frequency of at least 4 times per week can reduce the possibility of contracting cardiovascular disease, diabetes, and some cancers [3].

Regarding physical activity in Indonesia, the Ministry of Health of the Republic of Indonesia argues that participation in physical activities includes activities carried out by residents aged 15 years and over who are "heavy", "moderate" activities or walk for at least 10 minutes nonstop to every activity, and cumulative $>150$ minutes for 5 days a week. The World Health Organization (WHO) states that: "adults should accumulate at least 150 minutes per week of moderate-intensity aerobic physical activity, at least 75 minutes per week of vigorousintensity aerobic physical activity or an equivalent combination of moderate and vigorous physical activity." [5].

Initially, in accordance with the mandate of the law that every citizen has the same right to carry out sports activities, obtain services in sports activities, choose and follow the types or branches of sports that are in accordance with their talents and interests, obtain direction, support, guidance and development in sports, becoming a sportsman, and developing the sports industry. There used to be a slogan "Socializing Sports and sporting the community", but not equipped with management resources. In connection with that, the West Java Provincial Government, through the Department of Sports and Youth in 2010, has issued a Bachelor of Sports Development Trainer (SP3OR) with a total of 78 people distributed to $78 \mathrm{Sub}$ districts in 26 Regencies in West Java [6]. The main purpose of the deployment of SP3OR personnel is in order to encourage or motivate the West Java community to carry out activities or make sports a necessity and culture of life so that the community participation rate (APMO) of 50\% in 2016 can be 
achieved [6]. In its implementation there are several programs that can be carried out by SP3OR Personnel as a trigger to help and encourage the community to always behave actively. Some of these programs include the Sunday Sports Program, sports competition programs in the sub-district, community cultural self-defense programs, clean and healthy Friday programs, traditional sports programs.

\section{RESEARCH METHOD}

The method used in this research is survey. This method is very effective and is widely used to capture data from subjects in large numbers and that reach a wide range, such as research with the scope of national, regional or regional [4]. The survey was conducted in several sub-districts scattered throughout the regencies and cities in West Java. To obtain data on the number of sports community participation (APMO), researchers used questionnaires as instruments to obtain data. Questions in the questionnaire were designed to obtain information about community participation in sports. Indicators of sports community participation rates are seen from the frequency of sports carried out in one week. Questionnaire used as stated in table 1.

TABLE I. SURVEY OF COMMUNITY PARTICIPATION IN SPORTS

\section{SURVEY}

\section{INSTRUCTION}

Fill in the blanks or give a cross $(\mathrm{X})$ to the answer choices that are suitable for you. Your answer is not true or false, which is important according to the actual conditions.

\section{IDENTITY}

1. Name

2. Age

3. Gender : (1) Male $\quad$ (2) Female

4. Height Weight :

5. Current Job

(1) TNI / POLRI (2) Civil Servant (3) Employee Trader (5) Farmer

(6) Student

(7)

(4)

................................

Other

\section{QUESTIONS}

1. In the past week, have you been doing sports?
(1). Yes
(2). No

If you answer yes, continue to number 2

If you answer No, continue to number 9

2. How long have you been doing sports?
(1) $0-1$ Year
(2) $1-2$ Years
(3) $2-3$ Years
More than 3 years

3. How many times on average do you exercise in a week?

(1) Uncertain, sometimes doing it sometimes not
(2) Once
(3) Twice
(4) 3 Times
(5) More

Table 1. Cont
4. What is the average time for you to do exercise?
(1) 0 -30 minutes
(2) $30-60$ minutes
(3) $1-1,5$ hour (4) $1,5-2$ hours
(5) more than 2 hours

5. What sport do you mostly do?
(1) Football
(6) Basketball
(2) Volleyball
(7) Swimming
(3) Badminton
(8) Martial Art
(4) Athletics
Other,

(5) Gymnastics

6. What are your main goals for exercising?
(1) Maintaining health
(2) Losing weight

(3) Increasing networking

(4) achievement in sports

Getting

(5) Other :

7. Through what channels do you exercise?
(1) School
(2) Club
(3) Working

place (4) Alone

(5) Other :

8. Have you ever felt lazy to do sports activities?
(1) Ever
(2) Never

If you answer yes, continue to number 9

If you answer No, continue to number 10

9. Why don't you do sports?

(1) Do not have interest (2) Do not have time (3) There are no facilities / infrastructure (4) Tired (5) It's enough through the work I do (6) Other 10. In your opinion, how are the sports facilities in your area today?
(1) Adequate
(2) Less adequate
(3) Not adequate

\section{RESEARCH RESULTS}

Mobilizing SP3OR staff was a policy from the regional sports service (Disorda) of West Java Province referring to West Java Provincial Regulation Number 16 concerning West Java Provincial Technical Institutions and West Java Governor Decree Number 09 of 2009 concerning Main Tasks Functions and Details of Unit Tasks and Work Procedures at West Java regional sports service. As a regional technical institution that carries out a sports activities program in West Java, in 2010 Disorda West Java carried out the deployment of SP3OR Workers with the allocation of activities on 26 West Java in West Java.

Of the total population of 5,914,916 in 78 sub-distric of 26 Regencies/Cites in West Java, based on monitoring from SP3OR personnel, the initial data on public participation rates was recorded at $22.68 \%$. After the SP3OR personnel were demoted, in the implementation report until the end of 2012, the number of community participants in the exercise was 
$36.50 \%$ and there was an increase of $14 \%$. In 2013 the activities of deploying SP3OR personnel were not ongoing because the available budget was only sufficient for the implementation of the second generation SP3OR personnel selection test for the period of 2014-2016.

During the second year of service, there were 104 SP3OR staff distributed to 104 sub-districts in 25 regencies in West Java. The number of West Java community participation in sports in 2014 was $24.89 \%, 2015$ was $28.17 \%$ and in 2016 amounted to $32.04 \%$. As stated in fig. 1 .

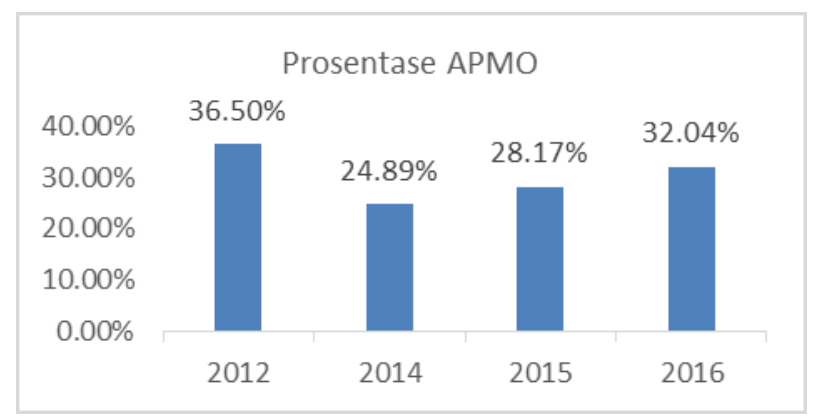

Fig. 1. Summary of APMO.

\section{CONCLUSION}

Based on data from the results of the study, the number of sports participation (APMO) still needs to be improved. Efforts to increase community participation in sports are still being carried out through sports programs carried out by the Bachelor of Sports Development Trainer (SP3OR) in each sub-district. In accordance with its function, SP3OR must be able to act as a motivator and driver of sports activities in the community. Motivating and mobilizing the community to exercise properly and sustainably. So that people will realize the importance of sports in maintaining health.

\section{REFERENCES}

[1] Undang-Undang Republik Indonesia No. 03 Tahun 2005 Tentang Sistem Keolahragaan Nasional.

[2] Badan Pusat Statistik, Statistik Pemuda Indonesia, 2015.

[3] A. Suherman, Membangun Kualitas Hidup Bangsa Melalui Pendidikan Jasmani. Naskah Pidato Pengukuhan Guru Besar FPOK UPI. Bandung, 2012

[4] M. Ali, Memahami Riset Perilaku dan Sosial. Bumi Aksara. Jakarta, 2014.

[5] A. Nawrocka, W. Garbaciak, J. Cholewa, W. Mynarski, The relationship between meeting of recommendations on physical activity for health and perceived work ability among white-collar workers. European journal of sport science. 2018 Mar 16;18(3):415-22.

[6] Pedoman kerja, Pengerahan Sarjana Pendamping Penggerak Pembangunan Olahraga. Disorda Prov. Jawa Barat, 2010. 